\title{
ESTIMATION OF WATER RETENTION AND AVAILABILITY IN SOILS OF RIO GRANDE DO SUL ${ }^{(1)}$
}

\author{
José Miguel Reichert ${ }^{(2)}$, Jackson Adriano Albuquerque ${ }^{(3)}$, Douglas Rodrigo \\ Kaiser $^{(4)}$, Dalvan José Reinert ${ }^{(2)}$, Felipe Lavarda Urach ${ }^{(5)} \& \operatorname{Reimar}_{\text {Carlesso }}{ }^{(6)}$
}

\section{SUMMARY}

Dispersed information on water retention and availability in soils may be compiled in databases to generate pedotransfer functions. The objectives of this study were: to generate pedotransfer functions to estimate soil water retention based on easily measurable soil properties; to evaluate the efficiency of existing pedotransfer functions for different geographical regions for the estimation of water retention in soils of Rio Grande do Sul (RS); and to estimate plant-available water capacity based on soil particle-size distribution. Two databases were set up for soil properties, including water retention: one based on literature data (725 entries) and the other with soil data from an irrigation scheduling and management system (239 entries). From the literature database, pedotransfer functions were generated, nine pedofunctions available in the literature were evaluated and the plant-available water capacity was calculated. The coefficient of determination of some pedotransfer functions ranged from 0.56 to 0.66 . Pedotransfer functions generated based on soils from other regions were not appropriate for estimating the water retention for RS soils. The plant-available water content varied with soil texture classes, from $0.089 \mathrm{~kg} \mathrm{~kg}^{-1}$ for the sand class to $0.191 \mathrm{~kg} \mathrm{~kg}^{-1}$ for the silty clay class. These variations were more related to sand and silt than to clay content. The soils with a greater silt/clay ratio, which were less weathered and with a greater quantity of smectite clay minerals, had high water retention and plant-available water capacity.

Index terms: pedotransfer functions, texture class, water retention curve, mineralogy.

\footnotetext{
(1) Parte da Dissertação de Mestrado do quinto autor apresentada ao Programa de Pós-graduação em Engenharia Agrícola, Universidade Federal de Santa Maria - UFSM. Pesquisa executada com recursos do CNPq. Recebido para publicação em dezembro de 2007 e aprovado em julho de 2009.

(2) Professor do Departamento de Solos, Centro de Ciências Rurais, Universidade Federal de Santa Maria - UfSM. Av. Roraima 1000, CEP 97105-900 Santa Maria (RS). Pesquisador do CNPq. E-mails: reichert@ccr.ufsm.br; dalvan@ccr.ufsm.br

(3) Professor do Departamento de Solos e Recursos Naturais, Universidade do Estado de Santa Catarina - UDESC. Av. Luis de Camões 2090, CEP 88520-000 Lages (SC). Pesquisador do CNPq. E-mail: albuquerque@pq.cnpq.br

(4) Doutorando em Ciência do Solo, UFSM. Bolsista da CAPES. E-mail: kaiser@mail.ufsm.br

${ }^{(5)}$ Mestre em Engenharia Agrícola, UFSM. E-mail: felurach@gmail.com

${ }^{(6)}$ Professor do Departamento de Engenharia Rural, UFSM. Pesquisador do CNPq. E-mail: carlesso@ccr.ufsm.br
} 


\title{
RESUMO: ESTIMATIVA DA RETENÇÃO E DISPONIBILIDADE DE ÁGUA EM SOLOS DO RIO GRANDE DO SUL
}

\begin{abstract}
Informações dispersas sobre retenção e disponibilidade de água em solos podem ser agrupadas em bancos de dados para gerar funções de pedotransferência. Os objetivos do trabalho foram: gerar equações de pedotransferência para estimar a retenção de água a partir de atributos do solo de fácil obtenção; avaliar a eficiência de pedofunções existentes para várias regiões para a estimativa da retenção de água em alguns solos do RS; e estimar a disponibilidade de água em função da distribuição do tamanho das partículas dos solos. Dois bancos de dados com atributos do solo, incluindo retenção de água foram organizados: um a partir de dados da literatura (725 dados) e outro de solos de um sistema de monitoramento e manejo de irrigação (239 dados). Com o banco da literatura foram geradas funções de pedotransferência, avaliadas nove pedofunções disponíveis na literatura e calculado o teor de água disponivel. As equações de pedotransferência geradas tiveram coeficientes de determinação entre 0,56 e 0,66. Equações de pedotransferência geradas com solos de outras regiões não foram adequadas para estimar a retenção de água de alguns solos do RS. O teor de água disponível variou em função da classe textural do solo, desde $0,089 \mathrm{~kg} \mathrm{~kg}^{-1}$ para a classe areia, a $0,191 \mathrm{~kg} \mathrm{~kg}^{-1}$ para a classe argilo siltosa. As variações foram mais dependentes das frações areia e silte do que da argila. Os solos com maior relação silte / argila, menos intemperizados e com maior quantidade de argilominerais do grupo das esmectitas, tiveram maior retenção e disponibilidade de água.
\end{abstract}

Termos de indexação: pedofunções, classe textural, curva de retenção de água, mineralogia.

\section{INTRODUCTION}

Plant-available water in the soil is essential for adequate crop growth and development and depends on the soil properties. For plants under water stress, the molecular and physiological processes are impaired (Ramos et al., 1999), which reduces crop development and yield. Plant-available water is measured directly, by the determination of gravimetric soil water content in a laboratory drying-oven or by indirect methods, with equipments such as the neutron probe and reflectometers. The accuracy of these methods is good, but they are very time-demanding or require the availability of expensive equipment, creating barriers to a large-scale use. To overcome these difficulties, some researchers have proposed mathematical models to estimate soil water retention (Meng et al., 1987; Arruda et al., 1987; Bell \& van Keulen, 1995; van den Berg et al., 1997; Pachepsky \& Rawls, 1999; Saxton \& Rawls, 2006), known as pedotransfer functions or equations (pedofunctions).

These models estimate water retention by means of soil properties that are more easily measurable or available in the literature and related to water retention, and which are generally related to capillarity and water adsorption phenomena (Rawls et al., 1991). The water retention curve expresses the soil water content based on its energy state at a given potential. The water retained at lower tensions has a greater relation to soil structure, while at higher tensions it is related to particle size distribution and soil mineralogy. Thus, pedotransfer functions may be generated when the particle size distribution, density, porosity and/or mineralogy of the soil are known (Rawls et al., 1991).

The available models were developed for temperate regions (Gupta \& Larson, 1979; Rawls et al., 1982; Saxton et al., 1986), where the edaphoclimatic properties are different, so their application in tropical regions may be unfeasible (Tomasella et al., 2000). In Brazil, some pedotransfer functions have already been established for estimating soil water retention (Arruda et al., 1987; Masutti, 1997; Giarola et al., 2002; Oliveira et al., 2002), but their validity for soils different from those of the database has been poorly investigated, making the degree of efficiency of a generalized use of these equations rather questionable.

The objectives of this study were: to generate pedotransfer functions to estimate soil water retention at different tensions based on easily measurable soil properties; to evaluate the efficiency of pedotransfer functions generated in other regions for the estimation of water retention in soils of Rio Grande do Sul (RS); and to calculate plant-available water capacity based on soil particle-size distribution of RS soils.

\section{MATERIAL AND METHODS}

The pedotransfer functions for the Rio Grande do Sul (RS), Brazil, soils were generated from data obtained from the literature (Kochhann, 1971; Righes, 1971; Cogo, 1972; Gomes, 1972; Curi, 1975; Abrão, 1977; Scopel, 1977; Cintra, 1980; Farias, 1981; Reichert, 1988; Salton, 1991; Costa, 1993; 
Vasconcellos, 1993; Carpenedo, 1994; Barcelos, 1996; Albuquerque, 1998; Rojas, 1998; Schäfer, 1999; Lima, 2001; Leitzke, 2002; Giarola et al., 2002; Peraza, 2003; Collares, 2005; Silva et al., 2005). These studies were based on samples collected from various representative soil classes and horizons in different regions of the State, resulting in a total of 725 datasets, which include water retention curves, organic matter, clay, silt and sand content, and bulk and particle density.

Data of water retention were available for the tensions of $1,6,10,33,100,300,400,500,900,1,000$, and $1,500 \mathrm{kPa}$. In some studies the retention curve was determined for up to eight tensions, while in others there is only one tension for water retention. The water retained at the tension of $10 \mathrm{kPa}$ was denominated as field capacity and that of $1,500 \mathrm{kPa}$ as permanent wilting point. The option was made to standardize the estimation of water retention at $10 \mathrm{kPa}$, determined in the laboratory, although the concept of field capacity for a given tension is questionable, as laid out by Hillel (1998), who argues that, in addition to soil properties such as texture and mineralogy, the effects of slope, sequence of the layers or horizons and other soil properties influence water retention as well.

For all samples, the particle size distribution (clay, silt and sand fractions) data is available, but in some studies the data are incomplete regarding organic matter content, bulk density, particle density or total porosity. In figure 1 the ample distribution of particle sizes in the dataset can be visualized, with samples in all textural classes, except for the silt textural class. There was a greater concentration in some classes such as loam, sandy loam, clay loam and clay.

Based on the database, multiple regression analyses were performed for the pedofunctions using the "stepwise" option (SAS, 1997). This method selects the independent variables: sand, silt, clay, organic

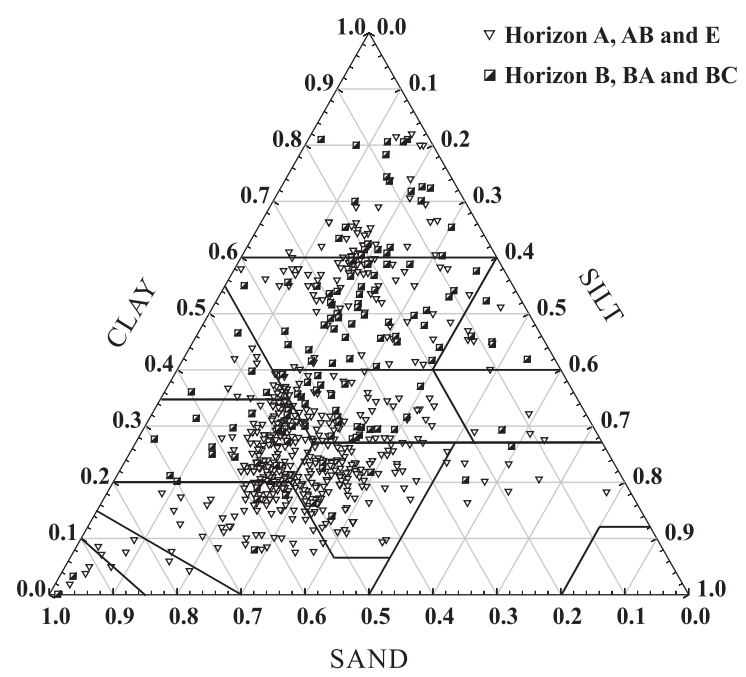

Figure 1. Soil textural classification used for derivation of the pedofunctions. matter, bulk density, particle density and the sum of the clay fractions plus silt (soil properties) and generates the respective coefficients that compose each pedofunction to estimate the water content retained by the soil at the tensions of $6,10,33,100,500$ and $1,500 \mathrm{kPa}$. Pedofunctions to estimate water retention for the tensions of 10,33 and $1,500 \mathrm{kPa}$ were also generated based on particle size distribution data only, which is necessary for databases that do not include the organic matter content and the bulk and particle densities.

For the determination of the multiple regressions, the complete database was used, because the separation in subsets did not improve the accuracy of the equations. Oliveira et al. (2002) also observed that the division of data into subsets based on the textural class, the activity of the clay fraction, or the degree of soil weathering did generally not improve the accuracy of the pedofunctions. Nevertheless, other researchers observed greater accuracy when separating soil groups in classes of soil texture, clay activity or pedogenetic horizons (van Genuchten, 1980; Wösten et al., 1995; Pachepsky \& Rawls, 1999).

The pedotransfer functions were tested by comparing the water content estimated by the proposed equations and those estimated by the pedofunctions proposed by Oliveira et al. (2002) and Masutti (1997) (Table 1). In addition, a dataset of an irrigation scheduling and management system (www.sistemairriga.com.br) was used, different from that used to generate the pedofunctions, so as to evaluate the accuracy of the estimations by the equations generated. This database contains the properties particle size distribution and water retention at the tensions of 33 and $1,500 \mathrm{kPa}$.

To evaluate the accuracy of other available equations, those that estimate the gravimetric soil water content were used, such as those proposed by Arruda et al. (1987), Oliveira et al. (2002), Bell \& van Keulen (1995) and Masutti (1997), and others that estimate the volumetric soil water content, as those proposed by Gupta \& Larson (1979), Rawls et al. (1982), Saxton et al. (1986), van den Berg et al. (1997), and Giarola et al. (2002) (Table 1), with data of organic matter, bulk density and clay, silt and sand content. The estimated soil water content for each model was correlated with the one measured.

Water content at field capacity $(-10 \mathrm{kPa})$, at the permanent wilting point $(-1,500 \mathrm{kPa})$ and plantavailable water capacity (between -10 and $-1,500 \mathrm{kPa}$ ) were calculated for each sample. The results were grouped by textural class and the mean of each class was presented in a textural triangle. For these properties, regression analysis was performed using program SAS (1997) and path analysis with the program Genes (2007), with result interpretion according to Cruz (2006). In this analysis, the data were submitted to descriptive statistics, Pearson correlation analysis and multicollinearity. Variables 
Table 1. Equations from the literature used to estimate water content of the soils from the database that gave origin to the proposed model

\begin{tabular}{|c|c|c|c|c|c|}
\hline $\begin{array}{l}\text { Literature } \\
\text { source }\end{array}$ & Soils & Tension & Model & Obs & $\mathbf{R}^{2}$ \\
\hline \multirow{4}{*}{$\begin{array}{l}\text { Gupta \& } \\
\text { Larson (1979) }\end{array}$} & \multirow{4}{*}{ USA } & $\mathrm{kPa}$ & & & \\
\hline & & 10 & $\theta\left(\mathrm{m}^{3} \mathrm{~m}^{-3}\right)=0,00502 *$ Sand $+0,00855^{*}$ Silt $+0,00883^{*}$ Clay $+0,00497^{*} \mathrm{OM}-0,242^{*} \mathrm{pb}$ & (2) & 0,96 \\
\hline & & 33 & $\theta\left(\mathrm{m}^{3} \mathrm{~m}^{-3}\right)=0,00308^{*}$ Sand $+0,00589^{*}$ Silt $+0,00804^{*}$ Clay $+0,00221^{*} \mathrm{OM}-0,143^{*} \mathrm{\rho b}$ & (2) & 0,96 \\
\hline & & 1,500 & $\theta\left(\mathrm{m}^{3} \mathrm{~m}^{-3}\right)=0,000059^{*}$ Sand $+0,00114^{*}$ Silt $+0,00577^{*}$ Clay $+0,00223^{*} \mathrm{OM}-0,0267^{*} \mathrm{\rho b}$ & (2) & 0,95 \\
\hline \multirow{3}{*}{$\begin{array}{l}\text { Rawls et al. } \\
(1982)\end{array}$} & \multirow[t]{3}{*}{ USA } & 10 & $\theta\left(\mathrm{m}^{3} \mathrm{~m}^{-3}\right)=0,412-0,003^{*}$ Sand $+0,0023^{*}$ Clay $+0,0317^{*} \mathrm{OM}$ & (2) & 0,81 \\
\hline & & 33 & $\theta\left(\mathrm{m}^{3} \mathrm{~m}^{-3}\right)=0,258-0,002^{*}$ Sand $+0,0036^{*}$ Clay $+0,0299^{*} \mathrm{OM}$ & (2) & 0,87 \\
\hline & & 1,500 & $\theta\left(\mathrm{m}^{3} \mathrm{~m}^{-3}\right)=0,026-0,005^{*} \mathrm{Clay}+0,016^{*} \mathrm{OM}$ & (2) & 0,80 \\
\hline \multirow{4}{*}{$\begin{array}{l}\text { Saxton et al. } \\
(1986)\end{array}$} & \multirow{4}{*}{ USA } & \multirow{4}{*}{10} & \multirow{2}{*}{$\theta\left(m^{3} m^{-3}\right)=\exp \left[\frac{(2.032-\operatorname{Ln} A)}{B}\right]$} & & \\
\hline & & & & & \\
\hline & & & $\mathrm{A}=\exp \left[-4,40-0,0715^{*}\right.$ Clay $-4,88 \cdot 10^{-4 *}$ Sand $^{2}-4,28 \cdot 10^{-5 *}$ Sand $^{2 *}$ Clay $] * 100$ & (2) & 0,99 \\
\hline & & & $\mathrm{B}=-3,14-2,22 \cdot 10^{-3 *}$ Clay $^{2}-3,48 \cdot 10^{-5 *}$ Sand $^{2 *}$ Clay & (2) & 0,99 \\
\hline \multirow{2}{*}{$\begin{array}{l}\text { Arruda et al. } \\
(1987)\end{array}$} & \multirow[t]{2}{*}{ SP - Brazil } & 33 & $\theta\left(\mathrm{g} 100 \mathrm{~g}^{-1}\right)=3,074+0,629^{*}($ Silt + Clay $)-0,003438^{*}(\text { Silt }+ \text { Clay })^{2}$ & $(1,2)$ & 0,91 \\
\hline & & 1,500 & $\theta\left(\mathrm{g} 100 \mathrm{~g}^{-1}\right)=1,074+0,2712^{*}($ Silt+Clay $)$ & $(1,2)$ & 0,95 \\
\hline \multirow{2}{*}{$\begin{array}{l}\text { Bell \& van } \\
\text { Keulen (1995) }\end{array}$} & \multirow[t]{2}{*}{ México } & \multirow[t]{2}{*}{1,500} & Model $1 \theta\left({\left.\mathrm{g} 100 \mathrm{~g}^{-1}\right)}=-0,992+0,351^{*}\right.$ clay $+0,47^{*} \mathrm{OM}$ & (2) & 0,85 \\
\hline & & & 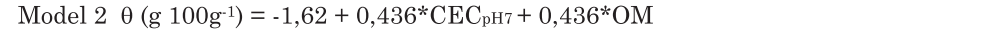 & (2) & 0,90 \\
\hline \multirow{2}{*}{$\begin{array}{l}\text { Van den Berg } \\
\text { et al. (1997) }\end{array}$} & \multirow{2}{*}{$\begin{array}{l}\text { Tropical } \\
\text { soils }\end{array}$} & 10 & $\theta\left(\mathrm{m}^{3} \mathrm{~m}^{-3} \cdot 10^{2}\right)=10,88+0,347^{*}$ Clay $+0,211^{*}$ Silt $+1,756^{\star} \mathrm{OC}$ & (2) & 0,86 \\
\hline & & 1,500 & $\theta\left(\mathrm{m}^{3} \mathrm{~m}^{-3} \cdot 10^{2}\right)=3,83+0,272 *$ Clay $+0,212^{*}$ Silt & (2) & 0,80 \\
\hline \multirow[t]{2}{*}{ Masutti (1997) } & \multirow[t]{2}{*}{ PE - Brazil } & 33 & $\theta\left(\mathrm{g} 100 \mathrm{~g}^{-1}\right)=-1,569+0,429^{*}($ Silt+Clay $)$ & (2) & \\
\hline & & 1,500 & $\theta\left(\mathrm{g} 100 \mathrm{~g}^{-1}\right)=-0,530+0,301 *$ Silt $+0,0928^{*}$ Clay & (2) & \\
\hline \multirow{3}{*}{$\begin{array}{l}\text { Giarola et al. } \\
(2002)\end{array}$} & \multirow{3}{*}{$\begin{array}{l}\text { RS e SC } \\
\text { Brazil }\end{array}$} & 10 & $\theta\left(\mathrm{m}^{3} \mathrm{~m}^{-3}\right)=0,081+0,005^{*}$ Silt $+0,004^{*}$ Clay & (2) & 0,79 \\
\hline & & 1,500 & A Horizon $\theta\left(\mathrm{m}^{3} \mathrm{~m}^{-3}\right)=-0,031+0,005^{*}$ Silt $+0,003^{*}$ Clay & (2) & 0,81 \\
\hline & & 1,500 & B Horizon $\theta\left(\mathrm{m}^{3} \mathrm{~m}^{-3}\right)=0,024+0,005^{*}$ Silt $+0,003^{*}$ Clay & (2) & 0,81 \\
\hline \multirow{2}{*}{$\begin{array}{l}\text { Oliveira et al. } \\
(2002)\end{array}$} & \multirow[t]{2}{*}{ PE - Brazil } & 33 & $\theta\left(\mathrm{kg} \mathrm{kg}^{-1}\right)=0,00333^{*}$ Silt $+0,00387^{*}$ Clay & (2) & 0,96 \\
\hline & & 1,500 & $\theta\left(\mathrm{kg} \mathrm{kg}^{-1}\right)=-0,00038^{*}$ Sand $+0,00153^{*}$ Silt $+0,00341^{*}$ Clay $-0,0309^{*} \mathrm{pb}$ & (2) & 0,95 \\
\hline
\end{tabular}

(1) The silt fraction has a diameter between 2 and $20 \mu \mathrm{m} .{ }^{(2)}$ Organic matter (OM), organic carbon (OC), sand, silt and clay in $\mathrm{g} 100 \mathrm{~g}^{-1}$. Bulk density $(\mathrm{\rho b})$ in $\mathrm{kg} \mathrm{dm}^{-3}$. CEC in $\mathrm{cmol}_{\mathrm{c}} \mathrm{kg}^{-1}$.

with high and severe multicollinearity were not included in the path analysis.

\section{RESULTS AND DISCUSSION}

\section{Soil physical properties and water retention}

Clay contents varied from 0.01 to $0.82 \mathrm{~kg} \mathrm{~kg}^{-1}$, silt from 0.01 to $0.78 \mathrm{~kg} \mathrm{~kg}^{-1}$ and sand from 0.01 to $0.99 \mathrm{~kg} \mathrm{~kg}^{-1}$. The organic matter content was 0.01 $0.10 \mathrm{~kg} \mathrm{~kg}^{-1}$ and bulk density $0.86-1.85 \mathrm{~kg} \mathrm{dm}^{-3}$ (Table 2). This ample variation is favorable and necessary for the generation of pedotransfer functions (Pachepsky \& Rawls, 1999). Thus, water retention also varied, as exemplified for the tension of $1,500 \mathrm{kPa}$, with levels of $0.01-0.48 \mathrm{~kg} \mathrm{~kg}^{-1}$. These differences reflect the parent material and the degree of weathering, and consequently the physical, chemical and mineralogical properties of the soil.

Water retention is positively correlated with the clay content (Table 3), because this fraction favors the occurrence of micropores and menisci that generate capillary forces. In addition, clay increases the specific surface area of the soil matrix and, consequently, water adsorption (Hillel, 1998). These two phenomena, capillarity and adsorption, determine the matric potential and are responsible for soil water retention. Consequently, soils whose constituents or structure favor the appearance of these two phenomena will retain a greater amount of water. 
Table 2. Descriptive statistics of the variables that compose the database used to generate the pedotransfer functions for RS soils

\begin{tabular}{|c|c|c|c|c|c|}
\hline Soil property & $\mathbf{n}^{(6)}$ & Minimum & Maximum & Mean & Standard deviation \\
\hline Clay $\left(\mathrm{kg} \mathrm{kg}^{-1}\right)$ & 725 & 0.01 & 0.82 & 0.33 & 0.17 \\
\hline Silt $\left(\mathrm{kg} \mathrm{kg}^{-1}\right)$ & 725 & 0.01 & 0.78 & 0.26 & 0.10 \\
\hline Sand $\left(\mathrm{kg} \mathrm{kg}^{-1}\right)$ & 725 & 0.01 & 0.99 & 0.41 & 0.16 \\
\hline Clay + Silt $\left(\mathrm{kg} \mathrm{kg}^{-1}\right)$ & 725 & 0.01 & 0.99 & 0.59 & 0.16 \\
\hline $\mathrm{OM}^{(1)}\left(\mathrm{kg} \mathrm{kg}^{-1}\right)$ & 366 & 0.00 & 0.10 & 0.02 & 0.02 \\
\hline$\rho \mathrm{b}^{(2)}\left(\mathrm{kg} \mathrm{dm}^{-3}\right)$ & 693 & 0.86 & 1.85 & 1.43 & 0.21 \\
\hline$\rho \mathrm{p}^{(3)}\left(\mathrm{kg} \mathrm{dm}^{-3}\right)$ & 725 & 1.96 & 3.22 & 2.63 & 0.11 \\
\hline$\phi \mathrm{t}^{(4)}\left(\mathrm{m}^{3} \mathrm{~m}^{-3}\right)$ & 693 & 0.29 & 0.68 & 0.46 & 0.08 \\
\hline$\theta \mathrm{g} \quad 6 \mathrm{kPa}^{(5)}\left(\mathrm{kg} \mathrm{kg}^{-1}\right)$ & 607 & 0.05 & 0.87 & 0.27 & 0.09 \\
\hline$\theta \mathrm{g} \quad 10 \mathrm{kPa}\left(\mathrm{kg} \mathrm{kg}^{-1}\right)$ & 358 & 0.04 & 0.77 & 0.26 & 0.10 \\
\hline$\theta \mathrm{g} \quad 33 \mathrm{kPa}\left(\mathrm{kg} \mathrm{kg}^{-1}\right)$ & 684 & 0.02 & 0.63 & 0.23 & 0.08 \\
\hline$\theta \mathrm{g} \quad 100 \mathrm{kPa}\left(\mathrm{kg} \mathrm{kg}^{-1}\right)$ & 645 & 0.02 & 0.52 & 0.20 & 0.07 \\
\hline$\theta \mathrm{g} \quad 500 \mathrm{kPa}\left(\mathrm{kg} \mathrm{kg}^{-1}\right)$ & 313 & 0.01 & 0.53 & 0.18 & 0.07 \\
\hline$\theta \mathrm{g} \quad 1,500 \mathrm{kPa}\left(\mathrm{kg} \mathrm{kg}^{-1}\right)$ & 685 & 0.01 & 0.48 & 0.17 & 0.06 \\
\hline
\end{tabular}

(1) OM: Organic matter. ${ }^{(2)} \mathrm{pb}$ : Bulk density. ${ }^{(3)} \rho \mathrm{p}$ : Particle density. ${ }^{(4)} \phi \mathrm{t}$ : Total porosity. ${ }^{(5)} \theta \mathrm{g}$ : Gravimetric soil water content at different tensions. ${ }^{(6)}$ n: number of samples with available data.

Table 3. Pearson correlation analysis between water retention at the tensions of $6,10,33,100,500$ and $1,500 \mathrm{kPa}$ with particle size distribution (clay, silt and sand), organic matter (OM), bulk density ( $\rho b)$, particle density $(\rho p)$ and total porosity $(\phi t)$

\begin{tabular}{|c|c|c|c|c|c|c|}
\hline Soil property & $\theta \operatorname{gg} 6^{(1)}$ & $\theta g 10$ & $\theta \mathrm{g} 33$ & $\theta g 100$ & $\theta g \mathbf{5 0 0}$ & $\theta g \mathbf{1 , 5 0 0}$ \\
\hline Clay & $0.49 * *(607)^{(2)}$ & $0.61 * *(358)$ & $0.56^{* *}(684)$ & $0.58^{* *}(645)$ & $0.59^{* *}(313)$ & $0.57 * *(685)$ \\
\hline Silt & $0.21^{* *}(607)$ & $0.29 * *(358)$ & $0.13^{* *}(684)$ & $0.18^{* *}(645)$ & $0.15^{* *}(313)$ & $0.01^{\mathrm{ns}}(685)$ \\
\hline Sand & $-0.64^{* *}(607)$ & $-0.73^{* *}(358)$ & $-0.68^{* *}(684)$ & $-0.70 * *(645)$ & $-0.69 * *(313)$ & $-0.66^{* *}(685)$ \\
\hline Silt + clay & $0.64^{* *}(607)$ & $0.73^{* *}(358)$ & $0.68^{* *}(684)$ & $0.70^{* *}(645)$ & $0.69^{* *}(313)$ & $0.66^{* *}(685)$ \\
\hline $\mathrm{OM}$ & $0.38^{* *}(253)$ & $0.40 * *(298)$ & $0.29 * *(325)$ & $0.39^{* *}(296)$ & $0.28^{* *}(251)$ & $0.29 * *(339)$ \\
\hline$\rho b$ & $-0.73^{* *}(603)$ & $-0.67 * *(354)$ & $-0.57^{* *}(652)$ & $-0.49^{* *}(641)$ & $-0.35^{* *}(313)$ & $-0.43^{* *}(653)$ \\
\hline$\rho p$ & $-0.01 \mathrm{~ns}(607)$ & $0.02^{\text {ns }}(358)$ & $-0.23 * *(684)$ & 0.07 ns $(645)$ & $0.18^{* *}(313)$ & $-0.14^{* *}(685)$ \\
\hline$\phi \mathrm{t}$ & $0.74^{* *}(603)$ & $0.67^{* *}(354)$ & $0.58^{* *}(652)$ & $0.50 * *(641)$ & $0.38^{* *}(313)$ & $0.44^{* *}(653)$ \\
\hline
\end{tabular}

(1) $\theta \mathrm{g}$ : Gravimetric soil water content. ${ }^{(2)}$ The number of data pairs used for calculation and correlation is indicated in brackets: **,

* and ns: significant at 1 and $5 \%$ and non significant.

\section{Estimation of water retention and validation of pedofunctions}

Due to the existence of soil variables in the RS soil database with direct and indirect relationships to water retention, it was possible to estimate water retention by pedotransfer functions (Table 4), as shown in figure 2 . The independent variables included in the equations were the same as the model presented by Gupta \& Larson (1979) and Rawls et al. (1982), and the coefficient associated with bulk density also had a negative signal, as in the cited study, which is due to the fact that sandier soils, with low water retention, are denser. In the model of van den Berg et al. (1997), the clay and silt contents better explained variation in water retention, which are variables also present in the model of Aina \& Periaswamy (1985) and Arruda et al. (1987) to describe water retention in tropical soils. This shows that some variables are frequently related in studies of estimation of soil water retention, of which clay is the principal variable (Wösten \& van Genuchten, 1988).

The coefficients of determination of the proposed pedofunctions varied from 0.56 at a tension of $500 \mathrm{kPa}$ to 0.67 at tensions of 6 and $10 \mathrm{kPa}$, all significant at the $1 \%$ level. Nevertheless, there are overestimates for low tensions and underestimates for high tensions, 
Table 4. Pedofunctions generated to estimate the gravimetric soil water content $\left(\mathrm{kg} \mathrm{kg}^{-1}\right)$ from data of Rio Grande do Sul soils, with all soil properties for the tensions of 6, 10, 33, 100, 500 and 1,500 kPa and with data from particle size distribution for the tensions of 6, 10 and 1,500 $\mathrm{kPa}$, by multiple regression analysis

\begin{tabular}{|c|c|c|c|}
\hline Equation & $\mathbf{R}^{2}$ Adjusted & $\operatorname{Pr}>\mathbf{F}$ & $\mathbf{n}$ \\
\hline \multicolumn{4}{|l|}{ Equations generated using all soil properties } \\
\hline$\theta$ ges $6=0.415+0.26 \times($ Clay + Silt $)+0.61 \times \mathrm{OM}-0.207 \times \rho b$ & 0.67 & 0.01 & 249 \\
\hline$\theta$ ges $10=0.268+0.05 \times$ Clay $+0.24 \times($ Clay + Silt $)+0.85 \times \mathrm{OM}-0.127 \times \rho b$ & 0.67 & 0.01 & 294 \\
\hline$\theta$ ges $33=0.106+0.29 \times($ Clay + Silt $)+0.93 \times \mathrm{OM}-0.048 \times \rho b$ & 0.62 & 0.01 & 293 \\
\hline$\theta$ ges $100=0.102+0.23 \times($ Clay + Silt $)-0.08 \times($ Silt + Sand $)+1.08 \times$ OM & 0.64 & 0.01 & 296 \\
\hline$\theta$ ges $500=0.268-0.11 \times$ Silt $-0.31 \times$ Are $+1.28 \times \mathrm{OM}+0.031 \times \rho b$ & 0.56 & 0.01 & 251 \\
\hline$\theta$ ges $1500=-0.04+0.15 \times$ Clay $+0.17 \times($ Clay + Silt $)+0.91 \times \mathrm{OM}+0.026 \times \rho b$ & 0.62 & 0.01 & 307 \\
\hline \multicolumn{4}{|l|}{ Equations generated using particle sizes } \\
\hline$\theta$ ges $10=0.037+0.38 \times($ Clay + Silt $)$ & 0.54 & 0.01 & 358 \\
\hline$\theta$ ges $33=0.366-0.34 \times$ Sand & 0.46 & 0.01 & 684 \\
\hline$\theta$ ges $1500=0.236+0.045 \times$ Clay $-0.21 \times$ Sand & 0.44 & 0.01 & 685 \\
\hline
\end{tabular}

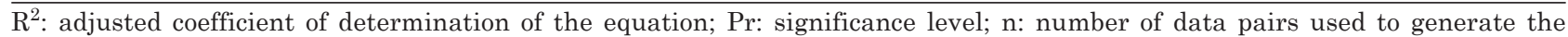
equation; $\theta$ ges: estimated gravimetric soil water content.

differences expressed in the angular coefficient, always $<1$, with variation from 0.56 to 0.67 (Table 5). The underestimation of the equations at high tensions was caused primarily by the presence of soils with a wide variation in mineralogy, since that to generate the pedofunctions all data collected in the literature were included. This same observation was reported by Tomasella et al. (2000) when establishing pedotransfer functions to estimate the coefficients of the van Genuchten equation, and by Williams et al. (1983) in a study of Australian soils.

The coefficients of determination of pedofunctions generated only with data of particle size distribution were 0.44 and 0.54 (Table 4), less than those of the equations that also use organic matter and bulk density, but which may be used when particle size distribution data are available.

Soil samples with high water retention at a tension of $100 \mathrm{kPa}$ were from horizons $\mathrm{A}$ and $\mathrm{A} / \mathrm{C}$ of a Gleysol and horizon B from a Vertisol. According to Kämpf et al. (1995), in Vertisols from the plateau region of RS, located in lower areas in the catena, the clay mineralogy is composed of montmorilonite-beidellite, whereas in more elevated areas, kaolinite, smectite and smectite with aluminum hydroxide predominate between layers. These authors also observed considerable differences in the cation exchange capacity of clay in the Vertisol horizons, from $56 \mathrm{cmol}_{\mathrm{c}} \mathrm{kg}^{-1}$ in the $\mathrm{C}$ to $18 \mathrm{cmol}_{\mathrm{c}} \mathrm{kg}^{-1}$ in the A horizon. The role of mineralogy in water retention was already discussed by Woodruf (1950), based on the particle diameter of the different minerals. Therefore, in addition to particle size distribution, water retention is highly dependent on soil mineralogy, which varies among soils and horizons. Baumer \& Brasher (1982) considered the effect of mineralogy in studies of soil water retention as an important variable. In a study by Puckett et al. (1985) in soils with similar mineralogy, the variables particle size distribution, bulk density and porosity were adequate to estimate water retention, while in soils with great mineralogical variation Hodnett \& Tomasella (2002) affirmed that mineralogy is a variable that significantly influences soil water retention and, when available, must be considered in the generation of pedotransfer functions.

\section{Evaluation of pedofunctions from the literature}

The equations generated with soil samples collected in Brazil, as well as the expression of van den Berg et al. (1997), which included soils from Brazil and from other tropical climate countries, are presented in figure 3a. Of these five models, that of Masutti (1997) at a tension of $33 \mathrm{kPa}$ and of Oliveira et al. (2002) at tensions of 33 and $1,500 \mathrm{kPa}$, were those that estimated water retention best, in spite of underestimating water retention at greater tensions. The model of Arruda et al. (1987) presents a gravimetric soil water content estimated at approximately $0.32 \mathrm{~kg} \mathrm{~kg}^{-1}$ at the tension of $33 \mathrm{kPa}$, while the measured contents are much higher. All models underestimate water retention at high tensions, which may be observed by the b coefficient of the proposed equation, which frequently has a value of $<0.5$. In figure $3 \mathrm{~b}$, results of the estimations with models developed with soils from Mexico and the USA were presented. Of these, the model of Bell \& van Keulen (1995) estimated the retention measured for 


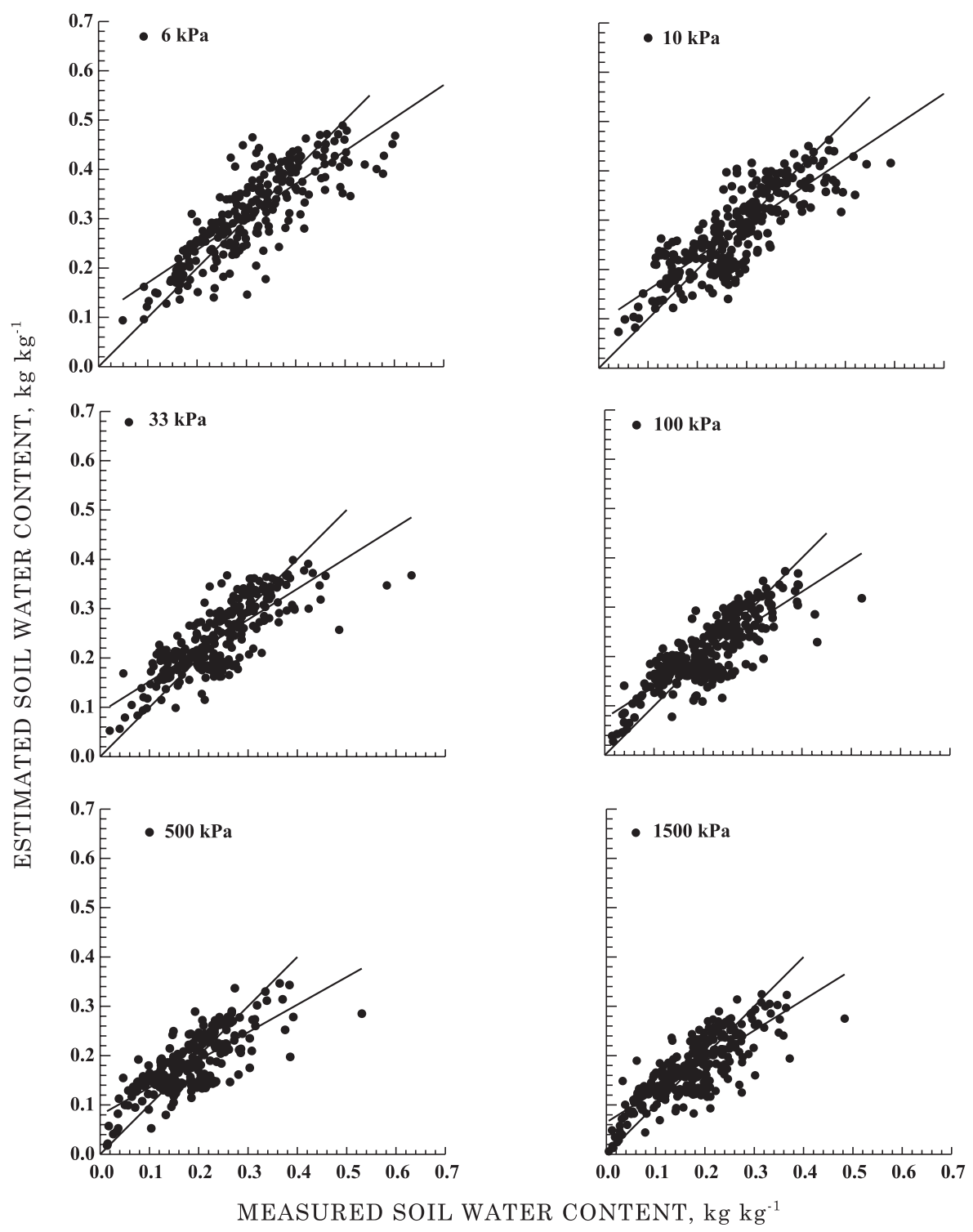

Figure 2. Relationship between the soil water content estimated by the pedofunctions proposed in table 4 and the soil water content measured in the laboratory for the tensions of $6,10,33,100,500$ and $1,500 \mathrm{kPa}$ in some RS soils. The straight line from the origin represents the 1:1 relation.

the soils of Rio Grande do Sul with greater accuracy. Nevertheless, the b coefficient of the equation was 0.61 (Table 5), different than 1 from the straight line 1:1. This indicates an underestimation of water retention at low tensions.

Models developed from soils of the temperate climate region, such as those of Gupta \& Larson (1979), Rawls et al. (1982) and Saxton et al. (1986), also under or overestimated water retention; nevertheless, dispersion was high (Figure 3b). With the exception of the model of Saxton et al. (1986) at a tension of $33 \mathrm{kPa}$, the other models had lower coefficients of determination than the models developed for soils in tropical regions. This may be due to differences in mineralogy between the soils in tropical and temperate climate regions.
The observations based on analysis of the models from the literature and of the model proposed in this study, clearly show the need for specific equations for soils with more homogeneous characteristics, as described by Arruda et al. (1987), Vereecken et al. (1989), Wösten et al. (1995), Salchow et al. (1996), and Pachepsky \& Rawls (1999). Nevertheless, for the data available, the grouping of soils by texture classes did not increase the coefficients of determination between water retention and soil properties (data not shown). Thus, mineralogy, which is quite variable in terms of soil classes and horizons, should be better studied, as emphasized by Baumer \& Brasher (1982), in order to quantify its relationship with water retention.

To evaluate the accuracy of the model proposed, the estimated results were compared with those 

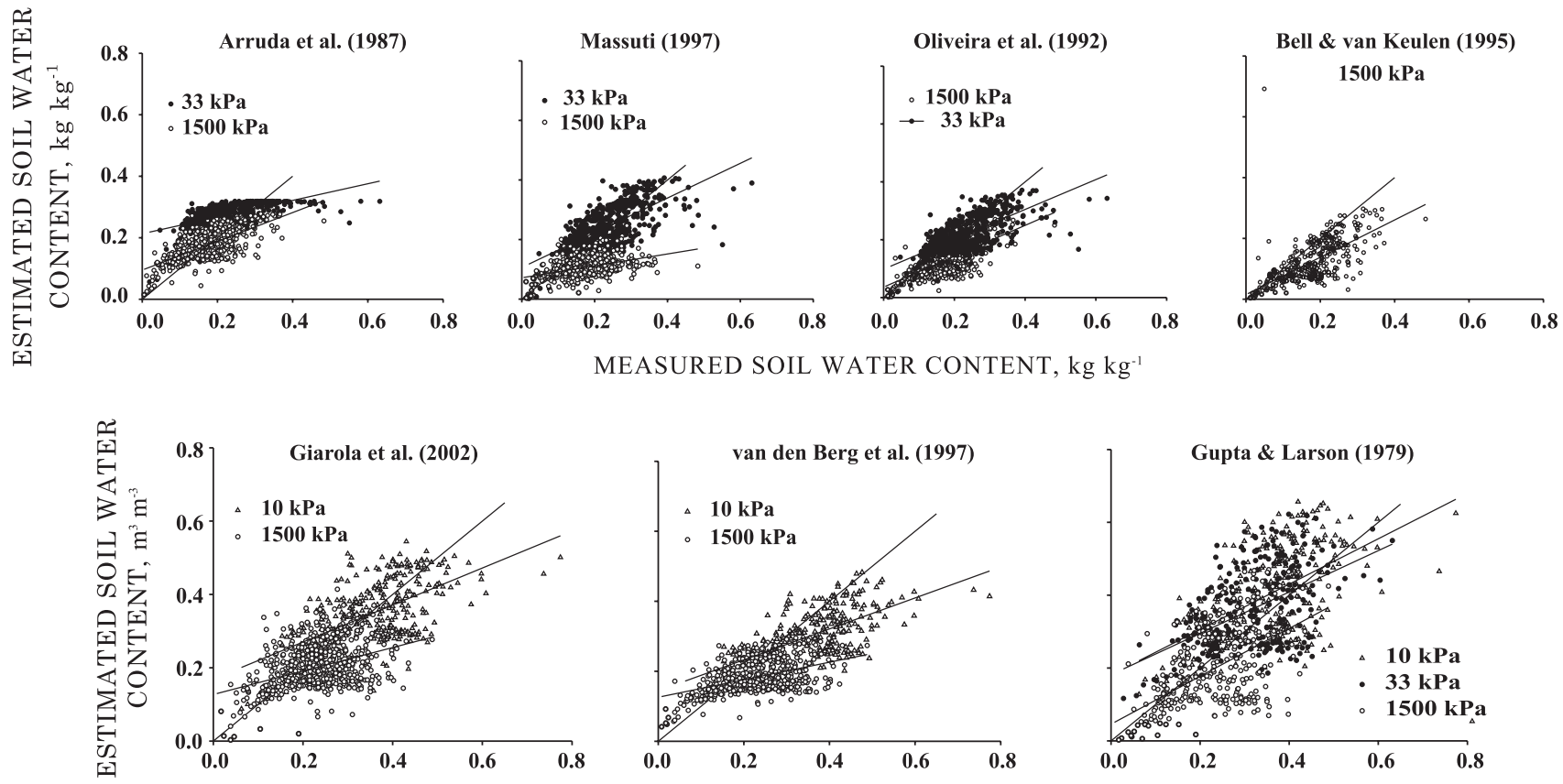

MEASURED SOIL WATER CONTENT, $\mathrm{m}^{3} \mathrm{~m}^{-3}$
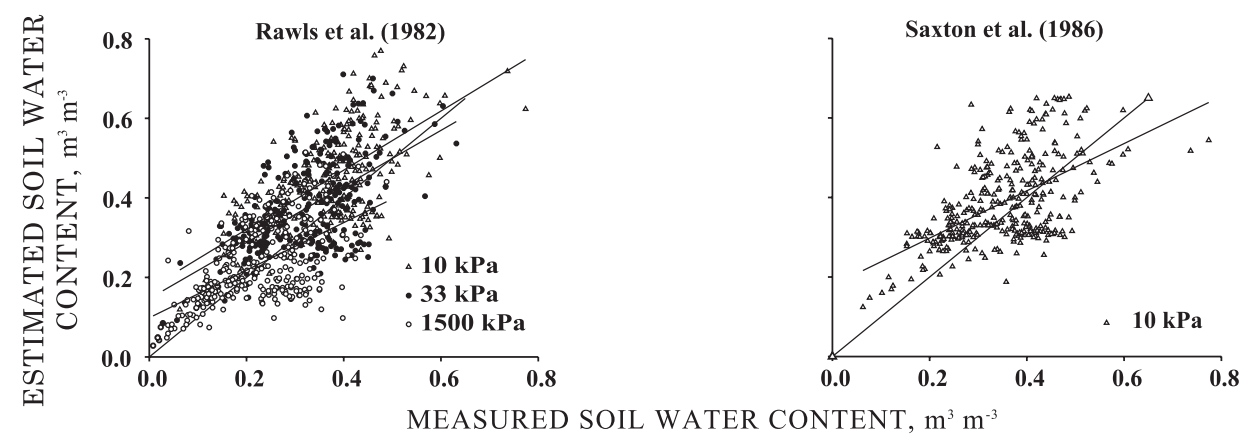

Figure 3. Comparison between soil water content estimated from published pedofunctions (Table 1: Arruda et al., 1987; Giarola et al., 2002; Masutti, 1997; Oliveira et al., 2002; van den Berg et al., 1997), based on soils from Brazil and of tropical climate, and from published pedofunctions (Table 1: Bell \& van Keulen, 1995; Gupta \& Larson, 1979; Rawls et al., 1982; and Saxton et al., 1986), based on soils from México and USA, and soil water content measured in soils of Rio Grande do Sul. The straight line is the 1:1 line.

estimated by the models of Oliveira et al. (2002) and of Masutti (1997), which were generated with data from the State of Pernambuco. The water retention estimated by the proposed model, compared to that estimated by the model of Oliveira et al. (2002) has an elevated coefficient of determination $(0.93$ for $33 \mathrm{kPa}$ to 0.92 for $1,500 \mathrm{kPa}$ ), but the model proposed overestimates water retention at the tension of $1,500 \mathrm{kPa}$ (Table 5 and Figure 4). For the model of Masutti (1997), the coefficients of determination were 0.46 at $33 \mathrm{kPa}$ and 0.94 at $1,500 \mathrm{kPa}$. In addition, the angular coefficient at $1,500 \mathrm{kPa}$ was only 0.42 , very different from the unit value, which indicates a significant underestimation.

With the objective of making equations available when there is only information regarding particle size distribution, three water retention equations were generated for the tensions of 10,33 and $1,500 \mathrm{kPa}$ (Table 4). For the tensions of 33 and $1,500 \mathrm{kPa}$, it was possible to evaluate the equations with the data available for soils from an irrigation system. It was observed that at a tension of $33 \mathrm{kPa}$, the coefficient of determination between the estimated and the measured soil water content was 0.73 , but 0.76 at $1,500 \mathrm{kPa}$ (Figure 5). For soils with low water retention, the estimated is greater than the measured soil water content. In addition, the slope of the straight line is different from the 1:1 line. For retention at $1,500 \mathrm{kPa}$ the estimated is greater than the measured soil water content in all samples. This may be the case because the soils underlying the proposed model have a mineralogy containing oxides, kaolinite and smectite, while in the database with the soils of the irrigation system the mineralogy consists 
Table 5. Statistical parameters and equations for the data and adjustments expressed in figures 2 to 5

\begin{tabular}{|c|c|c|c|c|c|c|}
\hline \multirow{2}{*}{ Adjusted equation } & \multirow{2}{*}{$\mathbf{n}^{(1)}$} & \multirow{2}{*}{$\mathbf{R}^{2}$} & \multirow{2}{*}{ MSE } & \multirow{2}{*}{$\operatorname{Pr}>\mathrm{F}$} & \multicolumn{2}{|c|}{$\operatorname{Pr}>\mathrm{T}$} \\
\hline & & & & & Intercept $=0$ & Slope $=1$ \\
\hline \multicolumn{7}{|c|}{ Figure 2} \\
\hline$\theta$ ges $6=0.103+0.67 \times$. gme $6(2)$ & 249 & 0.67 & $0.0028^{1}$ & 0.01 & 0.01 & 0.01 \\
\hline$\theta$ ges $10=0.092+0.66 \times$ ggme 10 & 294 & 0.67 & 0.0024 & 0.01 & 0.01 & 0.01 \\
\hline$\theta$ ges $33=0.090+0.63 \times$ agme 33 & 293 & 0.63 & 0.0019 & 0.01 & 0.01 & 0.01 \\
\hline$\theta$ ges $100=0.075+0.64 \mathrm{x} \theta$ gme 100 & 296 & 0.65 & 0.0015 & 0.01 & 0.01 & 0.01 \\
\hline$\theta$ ges $500=0.080+0.56 \times \quad \theta$ gme 500 & 251 & 0.56 & 0.0015 & 0.01 & 0.01 & 0.01 \\
\hline$\theta$ ges $1500=0.065+0.62 \times$ ogme 1500 & 307 & 0.62 & 0.0015 & 0.01 & 0.01 & 0.01 \\
\hline \multicolumn{7}{|c|}{ Figure $3 \mathrm{a}$} \\
\hline$\theta \operatorname{gAr} 33=0.213+0.27 \times \operatorname{xgme} 33$ & 684 & 0.38 & 0.0007 & 0.01 & 0.01 & 0.01 \\
\hline$\theta \operatorname{gAr} 1500=0.095+0.47 \times$ ogme 1500 & 685 & 0.43 & 0.0011 & 0.01 & 0.01 & 0.01 \\
\hline$\theta$ vGi $10=0.169+0.50 \times$ $\theta$ vme 10 & 354 & 0.37 & 0.0046 & 0.01 & 0.01 & 0.01 \\
\hline$\theta$ vGi $1500=0.127+0.32 \mathrm{x} \theta$ vme 1500 & 653 & 0.16 & 0.0030 & 0.01 & 0.01 & 0.01 \\
\hline$\theta \mathrm{gMa} 33=0.106+0.58 \mathrm{x}$ g gme 33 & 684 & 0.46 & 0.0024 & 0.01 & 0.01 & 0.01 \\
\hline$\theta \mathrm{gMa} 1500=0.072+0.20 \mathrm{x}$ 日gme 1500 & 685 & 0.18 & 0.0007 & 0.01 & 0.01 & 0.01 \\
\hline$\theta \mathrm{gOl} 33=0.098+0.52 \times$ agme 33 & 684 & 0.46 & 0.0019 & 0.01 & 0.01 & 0.01 \\
\hline$\theta \mathrm{gOl} 1500=0.036+0.53 \mathrm{x}$ $\theta$ gme 1500 & 653 & 0.40 & 0.0016 & 0.01 & 0.01 & 0.01 \\
\hline$\theta$ vBer $10=0.144+0.44 \mathrm{x} \theta$ vme 10 & 294 & 0.41 & 0.0031 & 0.01 & 0.01 & 0.01 \\
\hline$\theta$ vBer $1500=0.126+0.25 \mathrm{x}$ $\theta$ vme 1500 & 653 & 0.19 & 0.0015 & 0.01 & 0.01 & 0.01 \\
\hline \multicolumn{7}{|c|}{ Figure $3 \mathrm{~b}$} \\
\hline$\theta \mathrm{gBe} 1500=0.015+0.61 \mathrm{x} \quad \theta$ gme 1500 & 339 & 0.53 & 0.0021 & 0.01 & 0.01 & 0.01 \\
\hline$\theta$ vGu $10=0.181+0.62 \times$ vvme 10 & 294 & 0.28 & 0.0109 & 0.01 & 0.01 & 0.01 \\
\hline$\theta$ vGu $33=0.181+0.57 \times$ $\theta$ vme 33 & 293 & 0.26 & 0.0091 & 0.01 & 0.01 & 0.01 \\
\hline$\theta$ vGu $1500=0.046+0.66 \mathrm{x} \theta$ vme 1500 & 307 & 0.31 & 0.0087 & 0.01 & 0.01 & 0.01 \\
\hline$\theta \mathrm{vRa} 10=0.172+0.74 \mathrm{x}$ vvme 10 & 294 & 0.41 & 0.0088 & 0.01 & 0.01 & 0.01 \\
\hline$\theta$ vRa $33=0.145+0.70 \times$ $\theta$ vme 33 & 293 & 0.34 & 0.0085 & 0.01 & 0.01 & 0.01 \\
\hline$\theta$ vRa $1500=0.098+0.60 \times$ $\theta$ vme 1500 & 307 & 0.32 & 0.0068 & 0.01 & 0.01 & 0.01 \\
\hline$\theta \mathrm{vSa} 10=0.179+0.59 \mathrm{x} \theta$ vme 10 & 354 & 0.32 & 0.0078 & 0.01 & 0.01 & 0.01 \\
\hline \multicolumn{7}{|c|}{ Figure 4} \\
\hline$\theta \mathrm{gOl} 33=-0.026+1.01 \times$ g ges 33 & 334 & 0.93 & $0.0004^{\mathbf{T}}$ & 0.01 & 0.50 & 0.01 \\
\hline$\theta$ gOl $1500=-0.030+0.94 x$ - $\theta$ ges 1500 & 334 & 0.92 & 0.0003 & 0.01 & 0.01 & 0.01 \\
\hline$\theta \mathrm{gMa} 33=-0.040+1.17 \mathrm{x}$ $\theta$ ges 33 & 334 & 0.94 & 0.0005 & 0.01 & 0.01 & 0.01 \\
\hline$\theta$ gMa $1500=0.036+0.42 \times$ gges 1500 & 334 & 0.46 & 0.0008 & 0.01 & 0.01 & 0.01 \\
\hline \multicolumn{7}{|c|}{ Figure 5} \\
\hline$\theta$ ges $33=0.027+0.90$ gmI 33 & 239 & 0.73 & 0.0008 & 0.01 & 0.01 & 0.01 \\
\hline$\theta$ ges $1500=0.065+0.83 \times 0$ gmI 1500 & 239 & 0.76 & 0.0004 & 0.01 & 0.01 & 0.01 \\
\hline
\end{tabular}

${ }^{(1)} \mathrm{n}$ : number of data pairs to generate the equation; $\mathrm{R}^{2}$ : coefficient of determination; MSE: mean squared error; Pr $>\mathrm{F}$ : significance level for F test; Pr > T: significance level for T test. For the intercept, a significance level $>0.05$ indicates that the parameter "a" of the equation of the straight line does not differ from zero. For the slope, a significance level $>0.05$ indicates that the parameter

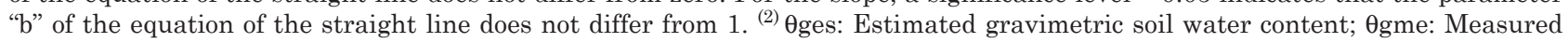
gravimetric soil water content; $\theta$ vme: Measured volumetric soil water content; $\theta$ gAr: Estimated gravimetric soil water content by the model of Arruda et al. (1987); ӨvGi: Estimated volumetric soil water content by the model of Giarola et al. (2002); $\theta$ gMa: Estimated gravimetric soil water content by the model of Masutti (1997); $\theta$ gOl: Estimated gravimetric soil water content by the model of Oliveira et al. (2002); Өvbr: Estimated volumetric soil water content by the model of van den Berg et al. (1997); $\theta$ gBe: Estimated gravimetric soil water content by the model of Bell \& van Keulen (1995); ӨvGu: Estimated volumetric soil water content by the model of Gupta \& Larson (1979); $\theta \mathrm{vRa}$ : Estimated volumetric soil water content by the model of Rawls et al.

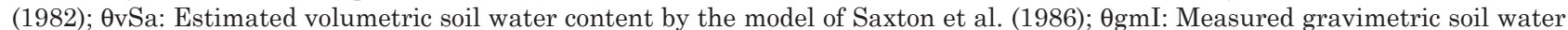
content from the irrigation database.

predominantly of kaolinite and iron oxides. Nevertheless, the estimation of soil water retention at $33 \mathrm{kPa}$, depending less on soil mineralogy and more on structure, was satisfactory.

Therefore, dispersion is greater and accuracy of water retention lower when we use equations generated from the database with predominance of soils of certain classes, or soils with characteristics that differ considerably from the soils where the model is being evaluated. Thus, the equations will only efficiently express water retention for soils that are similar in regard to their genesis and mineralogy (Williams et al., 1983; Mecke et al., 2002). When using pedotransfer functions created in other countries, Bonilla \& Cancino (2001) observed a low accuracy for Chilean soils. To overcome this limitation, it is necessary to work with a large database to allow a division of the soils into more homogeneous classes. 


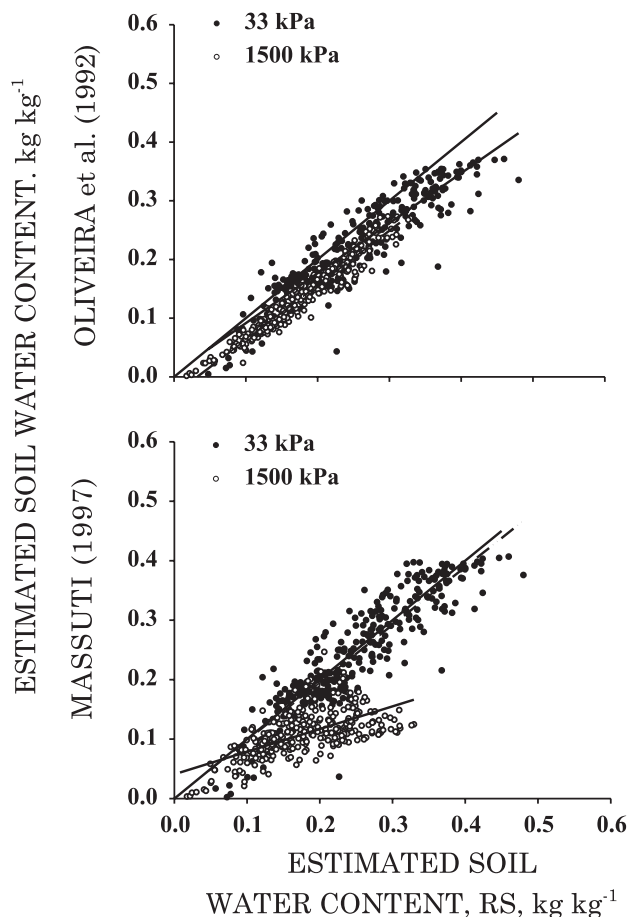

Figure 4. Relationship 1:1 between the gravimetric soil water content estimated by the proposed model ( $\theta$ ges) and that estimated by the model of Oliveira et al. (2002) ( $\theta \mathrm{gOl})$ and Masutti (1997) $(\theta \mathrm{gMa})$, for the tensions of 33 and $1,500 \mathrm{kPa}$.

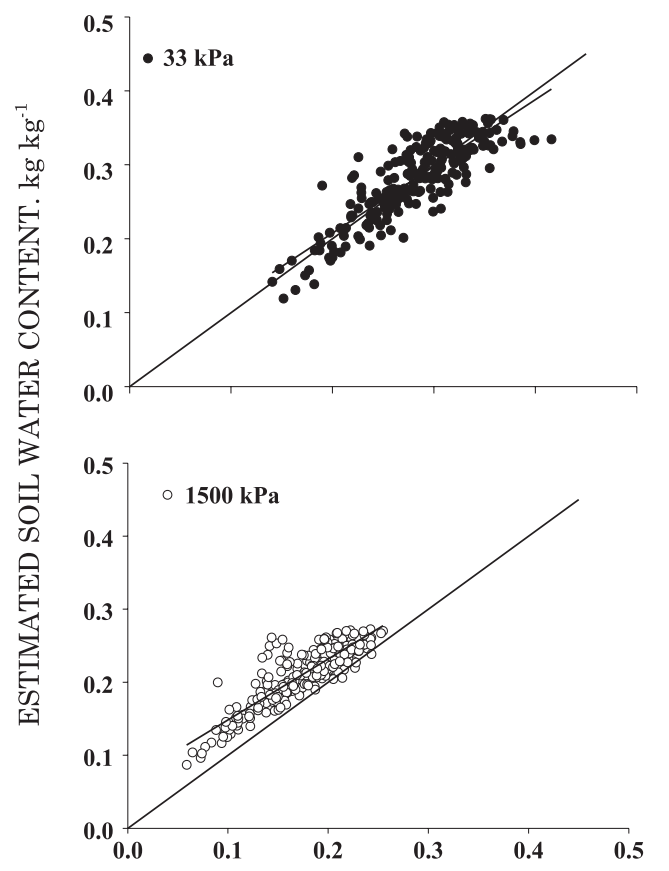

MEASURED SOIL WATER CONTENT, $\mathrm{kg} \mathrm{kg}^{-1}$

Figure 5. Ratio between the gravimetric soil water content measured for the soils of the irrigation system $(\theta \mathrm{gmI})$ and that estimated by the proposed model ( $\theta$ ges) for soils with particle size distribution information.

\section{Plant-available water for RS soils.}

Using path analysis, the direct and indirect effects of soil properties on water retention were evaluated (Table 6). For water retention at field capacity $(10 \mathrm{kPa})$, direct and positive effects of clay and silt are observed, and a negative effect of bulk density. The direct effect of clay $(R=0.71)$ is greater than its total effect $(R=0.62)$ due to its indirect effect through the silt content $(R=-0.23)$. In the more clayey soils, the silt content had a negative relationship with clay $(R=-0.42)$ and the lower direct contribution of the silt fraction to water retention $(R=0.54)$ diminishes the total effect of clay in that retention.

The total effect of bulk density was negative $(\mathrm{R}=$ $-0.65)$, a result of its direct effect $(R=-0.27)$ and indirect effect via the clay content $(R=-0.34)$. In denser soils, the volume of larger pores diminishes, affecting water retention at field capacity. With an increase in sand content, bulk density increased $(R=0.51)$; thus in the denser and sandier soils, water retention was less, which resulted in an indirect effect of particle size distribution in reducing field capacity in the denser soils. Therefore, sandier and denser soils with greater macroporosity and less microporosity than the clayey soils have a lower capacity for water retention (Casaroli \& Jong van Lier, 2008); however, in soil without variation of particle size distribution, compaction generally reduces total porosity and the volume of larger pores (Araujo et al., 2004). As shown by Klein \& Libardi (2002), soil cultivation in dryland and irrigated farming, compared to forest soil, generally increases water retention between tensions of 6 and $1,500 \mathrm{kPa}$, in the plant-available range, and also water retention in tensions $>1,500 \mathrm{kPa}$, unavailable to plants.

The organic matter content had a total positive effect on water retention at field capacity, with a correlation coefficient of 0.41 . The direct effect was low $(R=0.14)$, but indirect effect of clay $(R=0.04)$, silt $(R=0.15)$ and bulk density $(R=0.09)$ were responsible for the total effect (Table 6). This indicates that in soils with a greater clay plus silt content there is more organic matter $(\mathrm{R}=0.22)$, soil fractions that contribute to the additive effect on water retention by organic matter, as also observed by Bell \& van Keulen (1995) for soils in Mexico. Bauer \& Black (1992) affirmed that organic matter increases water retention more in sandy soils than in clayey soils.

Similar effects to those discussed for field capacity were observed for the permanent wilting point, however with different correlation coefficients (Table 6), primarily due to the lower direct effect of the silt fraction. Furthermore, for bulk density, the negative effect on water retention $(R=-0.44)$ was principally indirect via clay content $(R=-0.33)$ and from organic matter $(R=-0.04)$.

The water content retained at field capacity varied from $0.141 \mathrm{~kg} \mathrm{~kg}^{-1}$ in the sand class to $0.477 \mathrm{~kg} \mathrm{~kg}^{-1}$ 
Table 6. Correlation coefficients considering the direct and indirect effects obtained by path analysis between the contents of clay, silt, organic matter $(\mathrm{OM})$, bulk density $(\rho b)$ and particle density $(\rho p)$, with the gravimetric soil water content retained at field capacity $(10 \mathrm{kPa})$, at the permanent wilting point $(1,500 \mathrm{kPa})$ and the plant-available water capacity (retained between 10 and 1,500 kPa)

\begin{tabular}{|c|c|c|c|c|c|c|c|}
\hline \multirow{2}{*}{ Soil properties } & \multirow{2}{*}{$R$ total $^{(1)}$} & \multirow{2}{*}{ R-Direct effect } & \multicolumn{5}{|c|}{$R$ - Indirect effect } \\
\hline & & & Clay & Silt & OM & $\rho \mathbf{b}$ & $\rho \mathbf{p}$ \\
\hline \multicolumn{8}{|c|}{ Field capacity } \\
\hline Clay & 0.62 & 0.71 & & -0.23 & 0.01 & 0.13 & 0.00 \\
\hline Silt & 0.27 & 0.54 & -0.29 & & 0.04 & 0.00 & 0.00 \\
\hline $\mathrm{OM}$ & 0.41 & 0.14 & 0.04 & 0.15 & & 0.09 & 0.00 \\
\hline$\rho b$ & -0.65 & -0.27 & -0.34 & 0.00 & -0.04 & & 0.00 \\
\hline$\rho p$ & -0.06 & 0.01 & 0.05 & -0.06 & -0.02 & -0.05 & \\
\hline \multicolumn{8}{|c|}{ Permanent wilting point } \\
\hline Clay & 0.58 & 0.69 & & -0.16 & 0.01 & 0.01 & -0.01 \\
\hline Silt & 0.11 & 0.39 & -0.29 & & 0.03 & 0.00 & 0.01 \\
\hline $\mathrm{OM}$ & 0.29 & 0.12 & 0.04 & 0.11 & & 0.01 & 0.02 \\
\hline$\rho b$ & -0.44 & -0.03 & -0.33 & 0.00 & -0.04 & & -0.03 \\
\hline$\rho p$ & -0.15 & -0.14 & 0.05 & -0.04 & -0.01 & 0.00 & \\
\hline \multicolumn{8}{|c|}{ Available water } \\
\hline Clay & 0.06 & -0.02 & & -0.10 & 0.00 & 0.15 & 0.00 \\
\hline Silt & 0.22 & 0.23 & 0.01 & & 0.01 & 0.00 & -0.01 \\
\hline $\mathrm{OM}$ & 0.19 & 0.04 & 0.00 & 0.06 & & 0.10 & -0.01 \\
\hline$\rho b$ & -0.30 & -0.30 & 0.01 & 0.00 & -0.01 & & 0.01 \\
\hline$\rho p$ & -0.03 & 0.06 & 0.00 & -0.02 & 0.00 & -0.06 & \\
\hline
\end{tabular}

(1) Correlation coefficient.

in the silty clay class, while the permanent wilting point varied from $0.050 \mathrm{~kg} \mathrm{~kg}^{-1}$ in the sandy loam textural class to $0.286 \mathrm{~kg} \mathrm{~kg}^{-1}$ in the silty clay textural class (Figure 6). Both the field capacity and permanent wilting point increased in similar magnitude with the increase in clay content, which caused little changes in the plant-available water capacity with the increase of soil clay content (Figure 7). An exception was observed in the case of low clay contents, in the sand textural class, with less plant-available water capacity. Consequently, the plant-available water capacity increases when the clay content increases to near $0.15 \mathrm{~kg} \mathrm{~kg}^{-1}$, and remains constant thereafter (Figure 7).

The mean plant-available water capacity for the evaluated soils was $0.130 \mathrm{~kg} \mathrm{~kg}^{-1}$, with less retention in the sand textural class and greater in the silt clay textural class (Figure 6). Other classes with greater retention were the silty clay loam $\left(0.158 \mathrm{~kg} \mathrm{~kg}^{-1}\right)$ and silty loam $\left(0.176 \mathrm{~kg} \mathrm{~kg}^{-1}\right)$. In the other textural classes, the plant-available water capacity varied little with the particle size distribution, from $0.116 \mathrm{~kg} \mathrm{~kg}^{-1}$, in sandy clay loam, to $0.137 \mathrm{~kg} \mathrm{~kg}^{-1}$, in sandy clay soil. The lower plant-available water capacity in the sand textural class is related to the low specific surface area of these soils, while the greater availability in the silt clay class is related to the greater presence of clay and silt, with a larger specific surface area. When the three classes with greatest retention are analyzed, it is observed that these soils are less weathered and with a greater silt clay ratio and, therefore, greater contribution to water retention with $2: 1$ type minerals.

The path analysis showed that the plant-available water capacity had a positive total correlation with the silt content $(R=0.22)$ and organic matter $(R=$ 0.19 ), and a negative total correlation with bulk density $(R=-0.30)$. For the silt content and bulk density, the effects were direct, while for organic matter, the direct effect was small $(\mathrm{R}=0.04)$ and the total effect was related to the indirect effects via the silt content $(R=0.06)$ and bulk density $(R=0.10)$ (Table 6). Soils with greater organic matter content were those with greater silt content $(R=0.22)$; thus, the greater water retention of these soils was also via silt. Low correlation coefficients among soil properties and plant-available water capacity have frequently been reported (van den Berg et al., 1997; Giarola et al., 2002), probably due to the interactions with positive and negative effects among the soil properties, as verified by path analysis. 

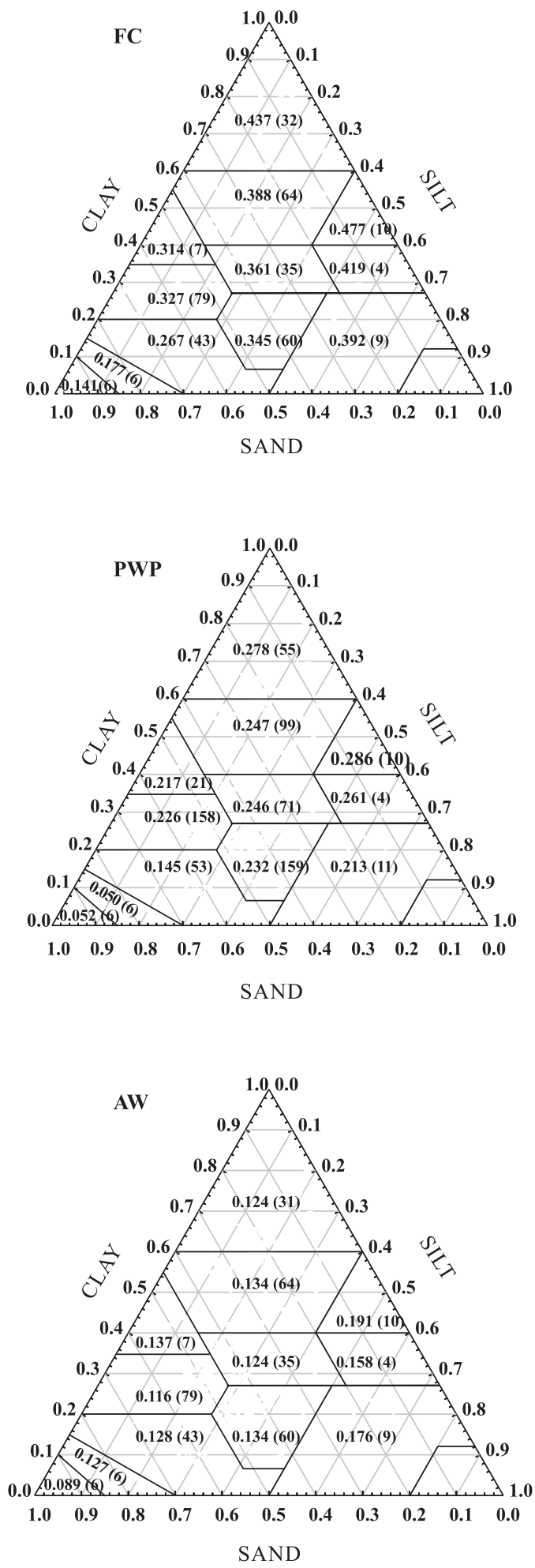

Figure 6. Water content $\left(\mathrm{m}^{3} \mathrm{~m}^{-3}\right)$ retained at the tensions of $10 \mathrm{kPa}(\mathrm{FC})$ and $1,500 \mathrm{kPa}(\mathrm{PWP})$ and plant-available water capacity retained between the tensions of 10 and $1,500 \mathrm{kPa}$ (AW), at the mean of each soil textural class, calculated from measured data. In brackets is the number of samples available for calculating each mean.

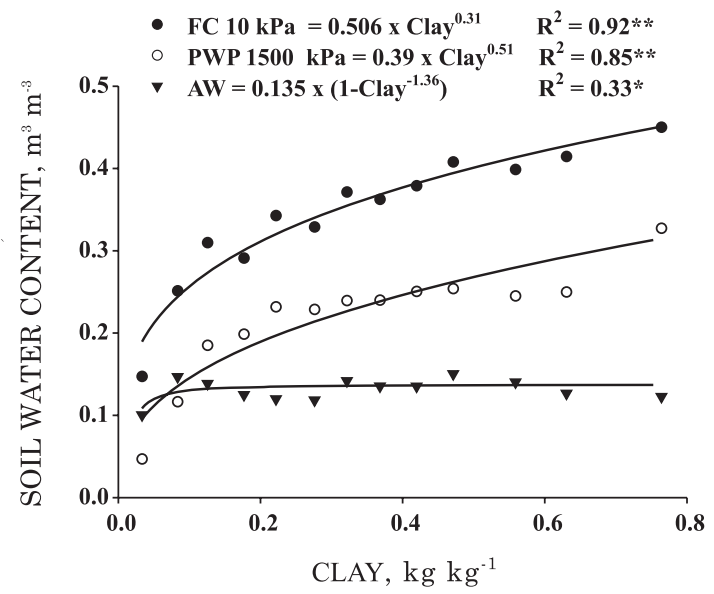

Figure 7. Relationship between the clay content in the soil and the water content at field capacity $(\mathrm{FC}=10 \mathrm{kPa})$, at the permanent wilting point $(\mathrm{PWP}=1,500 \mathrm{kPa})$ and the plant-available water capacity $(\mathrm{AW}=$ different between water content at 10 and at $1,500 \mathrm{kPa}$ ) for the $\mathrm{RS}$ soils.

\section{CONCLUSIONS}

1. Pedotransfer functions generated from soils of other geographical regions are not adequate for estimating water retention of the soils of RS.

2 . The proposed equations generally include the variables organic matter, bulk density and clay plus silt fractions.

3. The contents of clay, silt and organic matter had a total positive correlation with soil water content at field capacity and at the permanent wilting point, whereas bulk density had a negative correlation with water content at field capacity. Part of the correlation was due to an indirect effect, as a consequence of interrelationships which exist among soil properties.

4. The level of plant-available water capacity was lowest in the sand textural class due to the low specific surface area, while the greatest level was observed in the classes with a greater silt content and, therefore in those with a greater silt/clay ratio, indicating less weathered soils with a greater quantity of $2: 1$ type clay minerals.

\section{ACKNOWLEDGEMENTS}

The authors thank the agronomy graduate students Betânia Brum for her help with the execution of the path analysis, and the National Council of Scientific and Technological Development (CNPq) for granting Research Productivity Awards and financial resources for the study. 


\section{LITERATURE CITED}

ABRÃO, P.U.R. Características físico-hídricas e ocorrência provável de deficiência ou excesso de umidade em alguns solos da Campanha-Oeste do Rio Grande do Sul. Santa Maria, Universidade Federal de Santa Maria, 1977. 107p. (Tese de Mestrado)

AINA, P.O. \& PERIASWAMY, S.P. Estimating available waterholding capacity of Western Nigerian soils from soil texture and bulk density using core and sieved samples. Soil Sci., 140:55-58, 1985.

ALBUQUERQUE, J.A. Suscetibilidade de alguns solos do Rio Grande do Sul à erosão em entressulcos. Porto Alegre, Universidade Federal do Rio Grande do Sul, 1998. 154p. (Tese de Doutorado)

ARAUJO, M.A.; TORMENA, C.A. \& SILVA, A.P. Propriedades físicas de um Latossolo Vermelho distrófico cultivado e sob mata nativa. R. Bras. Ci. Solo, 28:337-345, 2004.

ARRUDA, F.B.; JÚLIO Jr., J. \& OLIVEIRA, J.B. Parâmetros de solo para cálculo de água disponível com base na textura do solo. R. Bras. Ci. Solo, 11:11-15, 1987.

BARCELOS, A.A. Infiltração de água em um Latossolo, sob chuva de alta intensidade, em diferentes sistemas de manejo. Porto Alegre, Universidade Federal do Rio Grande do Sul 1996. 112p. (Tese de Mestrado)

BAUER, A. \& BLACK, A.L. Organic carbon effects on available water capacity of three soil textural groups. Soil Sci. Soc. Am. J., 56:248-254, 1992.

BAUMER, O.W. \& BRASHER, B.R. Prediction of water content at selected suctions. Madison, American Society of Agricultural Engineers, 1982. (ASAE Paper, 82-2590)

BELL, M.A. \& van KEULEN, H. Soil pedotransfer functions for four Mexicans soils. Soil Sci. Soc. Am. J., 59:865-871, 1995.

BONILLA, M.C. \& CANCINO, V.J. Estimación del contenido de humedad del suelo mediante el empleo de funciones de pedotransferência. Agric. Tec, 61:326-338, 2001.

CARPENEDO, V. Compressibilidade de solos em sistemas de manejo. Porto Alegre, Universidade Federal do Rio Grande do Sul, 1994. 106p. (Tese de Doutorado)

CASAROLI, D.; JONG VAN LIER, Q. Critérios para a determinação da capacidade de vaso. R. Bras. Ci. Solo, 32:59-66, 2008.

CINTRA, F.L.D. Caracterização do impedimento mecânico em Latossolos do Rio Grande do Sul. Porto Alegre, Universidade Federal do Rio Grande do Sul, 1980. 89p. (Tese de Mestrado)

COGO, N.P. Morfologia e gênese de solos escuros formados sobre basalto na Campanha-Oeste do Rio Grande do Sul. Porto Alegre, Universidade Federal do Rio Grande do Sul, 1972. 131p. (Tese de Mestrado)

COLLARES, G.L. Compactação em Latossolos e Argissolo e relações com parâmetros de solo e de plantas. Santa Maria, Universidade Federal de Santa Maria, 2005. 106p. (Tese de Doutorado)
COSTA, A.E.M. Quantificação de atributos físicos de solos de várzea, relacionados com a disponibilidade de água, o espaço aéreo e a consistência do solo. Pelotas, Universidade Federal de Pelotas, 1993. 134p. (Tese de Mestrado)

CRUZ, C.D. Programa Genes: Estatística experimental e matrizes. Viçosa, MG, Universidade Federal de Viçoa, 285p. 2006.

CURI, N. Relações genéticas e geomorfológicas em solos das encostas inferior e superior do nordeste do Rio Grande do Sul. Porto Alegre, Universidade Federal do Rio Grande do Sul, 1975. 149p. (Tese de Mestrado)

FARIAS, G.S. Efeito de sistemas de cultivo sobre a porosidade e retenção de água de um solo Laterítico Bruno Avermelhado distrófico (Paleudult). Porto Alegre, Universidade Federal do Rio Grande do Sul, 1981. 78p. (Tese de Mestrado)

GENES - Aplicativo computacional em genética e estatística. 2007. Disponível em:<www.ufv.br/dbg/genes/genes.htm>

GIAROLA, N.F.B.; SILVA, A.P. \& IMHOFF, S. Relações entre propriedades físicas e características de solos da Região Sul do Brasil. R. Bras. Ci. Solo, 26:885-893, 2002.

GOMES, A.S. Relações solo-água em solos Argilosos-Escuros da Campanha Sudoeste do Rio Grande do Sul. Porto Alegre, Universidade Federal do Rio Grande do Sul, 1972. 94p. (Tese de Mestrado)

GUPTA, S.C. \& LARSON, W.E. Estimating soil water retention characteristics from particle size distribution, organic matter percent, and bulk density. Water Res. Res., 15:16331635, 1979.

HILLEL, D. Environmental soil physics. San Diego, Academic Press, 1998. 771p.

HODNETT, M.G. \& TOMASELLA, J. Marked differences between van Genuchten soil water-retention parameters for temperate and tropical soils: A new water-retention pedo-transfer functions developed for tropical soils. Geoderma, 108:155-180, 2002.

KÄMPF, N.; SCHNEIDER, P. \& MELLO, P.F. Alterações mineralógicas em seqüência Vertissolo-Litossolo na região da Campanha do Rio Grande do Sul. R. Bras. Ci. Solo, 19:349-357, 1995 .

KLEIN, V. \& LIBARDI, P.L. Densidade e distribuição do diâmetro dos poros de um Latossolo Vermelho, sob diferentes sistemas de uso e manejo. R. Bras. Ci. Solo, $26: 857-867,2002$.

KOCHHANN, R.A. Levantamento detalhado e classificação de capacidade de uso e irrigação dos solos do Posto Agropecuário de Carazinho-RS. Porto Alegre, Universidade Federal do Rio Grande do Sul, 1971. 100p. (Tese de Mestrado)

LEITZKE, V.W. Armazenagem e disponibilidade de água de solos construídos na área de mineração de carvão de Candiota-RS. Pelotas, Universidade Federal de Pelotas, 2002. 129p. (Tese de Mestrado)

LIMA, A.C.R. Caracterização hidráulica de um Planossolo sob diferentes sistemas de manejo. Pelotas, Universidade Federal de Pelotas, 2001. 73p. (Tese de Mestrado) 
MASUTTI, M.M. Caracterização da água disponível a partir de parâmetros físico-hídricos em solos da zona da mata do Estado de Pernambuco. Recife, Universidade Federal Rural de Pernambuco, 1997. 69p. (Tese de Mestrado)

MECKE, M.; WESTMAN, C.J. \& ILVESNIEMI, H. Water retention capacity in coarse Podzol profiles predicted from measured soil properties. Soil Sci. Soc. Am. J., 66:1-11, 2002 .

MENG, T.P.; TAYLOR, H.M.; FRYREAR, D.W. \& GOMEZ, J.F. Models to predict water retention in semiarid sandy soil. Soil Sci. Soc. Am. J., 5:1563-1565, 1987.

OLIVEIRA, L.B.; RIVEIRO, M.R.; JACOMINE, P.K.T.; RODRIGUES, J.J.V. \& MARQUES, F.A. Funções de pedotransferência para predição da umidade retida a potenciais específicos em solos do Estado de Pernambuco. R. Bras. Ci. Solo, 26:315-323, 2002.

PACHEPSKY, Y.A. \& RAWLS, W.J. Accuracy and reliability of pedotransfer functions as affected by grouping soils. Soil Sci. Soc. Am. J., 63:1748-1757, 1999.

PERAZA, J.E.S. Retenção de água e pedofunções para solos do Rio Grande do Sul. Santa Maria, Universidade Federal de Santa Maria, 2003. 118p. (Tese de Mestrado)

PUCKETT, W.E.; DANE, J.H. \& HAJEK, B.F. Physical and mineralogical data to determine soil hydraulic properties. Soil Sci. Soc. Am. J., 49:831-836, 1985.

RAMOS, M.L.G.; GORDON, A.J.; MINCHIN, F.R.; SPRENT, J.I. \& PARSONS. R. Effect of water stress on nodule physiology and biochemistry of a drought tolerant cultivar of common bean. Ann. Bot., 83:57-63, 1999.

RAWLS, W.J.; BRAKENSIEK, D.L. \& SAXTON, K.E. Estimation of soil water properties. Trans. Am. Soc. Agric. Eng., 25:1316-1320, 1982.

RAWLS, W.J.; GISH, T.J. \& BRAKENSIEK, D.L. Estimating soil water retention from soil physical properties and characteristics. Adv. Soil Sci., 16:213-234, 1991.

REICHERT, J.M. Formação de selo superficial e infiltração de água sob chuva simulada em solos do Rio Grande do Sul. Porto Alegre, Universidade Federal do Rio Grande do Sul, 1988. 165p. (Tese de Mestrado)

RIGHES, A.A. Efeitos da irrigação e drenagem em três épocas de semeadura, na cultura do milho em resteva de arroz. Porto Alegre, Universidade Federal do Rio Grande do Sul, 1971. 145p. (Tese de Mestrado)

ROJAS, C.A.L. Alterações físico-hídricas de um Podzólico em função do manejo do solo. Porto Alegre, Universidade Federal do Rio Grande do Sul, 1998. 76p. (Tese de Mestrado)

SALCHOW, E.; LAL, R.; FAUSEY, N. \& WARD, A. Pedotransfer functions for variable alluvial soils in Southern Ohio. Geoderma, 73:165-181, 1996.

SALTON, J.C. Relações entre sistemas de preparo, temperatura e umidade do solo. Porto Alegre, Universidade Federal do Rio Grande do Sul, 1991. 92p. (Tese de Mestrado)
SAS Institute. SAS Statistical Package, version 6.12. Cary, 1997.

SAXTON, K.E. \& RAWLS, W.J. Soil water characteristic estimates by texture and organic matter for hydrologic solutions. Soil Sci. Soc. Am. J., 70:1569-1578, 2006.

SAXTON, K.E.; RAWLS, W.J.; ROMBERGER, J.S. \& PAPENDICK, R.I. Estimating generalized soil-water characteristics from texture. Soil Sci. Soc. Am. J., 50:10311036, 1986.

SCHÄFER, M.J. Erosão em entressulcos e em sulcos sob diferentes preparos e consolidação do solo. Santa Maria, Universidade Federal de Santa Maria, 1999. 139p. (Tese de Mestrado).

SCOPEL, I. Características físicas de solos da Região LitoralNorte do Rio Grande do Sul. Porto Alegre, Universidade Federal do Rio Grande do Sul, 1977. 120p. (Tese de Mestrado)

SILVA, M.A.S.; MAFRA, A.L.; ALBUQUERQUE, J.A.; BAYER, C. \& MIELNICZUK, J. Atributos físicos do solo relacionados ao armazenamento de água em um Argissolo Vermelho sob diferentes sistemas de preparo. Ci. Rural, 35:544-552, 2005.

TOMASELLA, J.; HODNETT, M.G. \& ROSSATO, L. Pedotransfer functions for the estimation of soil water retention in Brazilian soils. Soil Sci. Soc. Am. J., 64:327338,2000

van den BERG, M.; KLAMT, E.; van REEUWIJK, L.P. \& SOMBROEK, W.G. Pedotransfer functions for estimation of moisture retention characteristics of Ferralsols and related soils. Geoderma, 78:161-180, 1997.

van GENUCHTEN, M.Th. A closed-form equation for predicting the hydraulic conductivity of unsaturated soils. Soil Sci. Soc. Am. J., 44:892-898, 1980

VASCONCELLOS, E.B. Atributos físicos de três solos de várzea do Rio Grande do Sul. Pelotas, Universidade Federal de Pelotas, 1993. 120p (Tese de Mestrado)

VEREECKEN, H.J.; MAES, J.; FEYEN, J. \& DARIUS, P. Estimating the soil moisture retention characteristic from texture, bulk density, and carbon content. Soil Sci., 148:389-403, 1989

WILLIAMS, J.; PREBBLE, R.E.; WILLIAMS, W.T. \& HIGNETT, C.T. The influence of texture, structure and clay mineralogy on the soil moisture characteristic. Aust. J. Soil Res., 21:15-32, 1983.

WÖSTEN J.H.M. \& van GENUCHTEN, M.Th. Using texture and other soil properties to predict the unsaturated soil hydraulic functions. Soil Sci. Soc. Am. J., 52:1762-1770, 1988.

WÖSTEN J.H.M.; FINKE P.A. \& JANSEN M.J.W. Comparison of class and continuous pedotransfer functions to generate soil hydraulic characteristics. Geoderma, 66:227237,1995

WOODRUF, C.M. Water retention by clay. Soil Sci. Soc. Am. Proc., 15:54-57, 1950. 